\title{
Towards a World History of Economic Thought: A China Monetary Perspective
}

\author{
Niv Horesh \\ China Studies, School of Humanities and Communication Arts, Western Sydney University, Sydney, Australia \\ Email: niv.horesh@gmail.com
}

How to cite this paper: Horesh, N. (2022) Towards a World History of Economic Thought: A China Monetary Perspective. Open Journal of Social Sciences, 10, 171-179. https://doi.org/10.4236/jss.2022.102011

Received: January 10, 2022

Accepted: February 15, 2022

Published: February 18, 2022

Copyright (c) 2022 by author(s) and Scientific Research Publishing Inc. This work is licensed under the Creative Commons Attribution International License (CC BY 4.0).

http://creativecommons.org/licenses/by/4.0/

\begin{abstract}
The history of economic thought was arguably the most Eurocentric and Modernocentric subfield of economics. Most primers and readers in the English language used to deal with early modern Europe to the exclusion of other regions. The purpose of this research note is therefore to tentatively revisit famous and lesser-known thinkers across Eurasia, by way of encouraging more inclusive comprehensive accounts of economic thought in pre-modern and early modern times. The issues covered will be mercantile policy; usury and interest rates; taxation; and finally and most importantly monetary thought. The conclusions show that monetary nominalism was pervasive around the world; and that Islamic thinkers were the least anti-mercantile.
\end{abstract}

\section{Keywords}

History of Economic Thought, China, India, Islam, Usury, Prices, Tax, Money

\section{Introduction}

The history of economic thought was arguably the most Eurocentric and Modernocentric subfield of economics. Until recently, most primers and readers in the English language used to deal with early modern Europe to the exclusion of other regions (Barber, 1967; Medema \& Samuels, 2013; Sandelin Trautwein \& Wundrak, 2014).

That China and India for example were the hotbed of profound economic thinking was considered inherently separate rather than of comparative value (Hu, rep. 2009; Dasgupta, 2002). The proof is that hardly ever these two regions were included in volumes on "world" history of economic thought. It is only in the last few years that Western scholars have tried to offer historical accounts of 
the formative economic ideas, politics and philosophies across the major civilizations of Eurasia stretching right back to antiquity (Barnett ed., 2014; Schefold \& Amelung, ed., 2021; Pines \& Shelach, 2005).

This is surprising given that luminaries like Geert Hofstede (1928-2020) or Ludwig von Mises (1881-1973) stressed the significance of culture and language to the emergence of differing economic ideas (Hofstede, 1984; Ludwig von Mises, rep. 2005). The Spanish arbitristas, in turn, looked for the difference between nations beyond culture and language. They came to the conclusion, much like the Dutch curse concept of modern times, that too many natural resources lead to laziness, and the their proof was Castille. Nations that were resource poor were on the other hand industrious (Rauschenbach \& Windler, 2016).

On another count, the medieval Muslim scholar al-Birumi (973-1050), and the Chinese early modern scholar Hong Liangji (1746-1809) are both respectively said to have pre-saged Malthus (1766-1834); Ibn Khaldun (1332-1406) apparently inspired the much later Laffer Curve; Bernard Mandeville's (1670-1733) and Jean François de Saint-Lambert's (1716-1803) ideas about self-interest and luxury consumption which are perfectly reflected in the thought of earlier Chinese scholars-intellectuals like Lu Ji (1515-52) or Tang Zhen (1630-1704), thus problematizing the uniqueness of European Enlightenment (Zanasi, 2015: p. 460). Earlier still we even find hedonist Yang Zhu (BCE 440-360) with similar ideas.

Therefore, the purpose of this research note is to revisit famous and lesser-known thinkers across Eurasia, by way of encouraging more inclusive accounts of economic thought in pre-modern and early modern times. The cut-off will be the mid- $18^{\text {th }}$ Century as this is when classical ideas started diffusing globally, partly glossing over the sort of differences that Hofstede and Mises stressed. The endpoint, more precisely, will be the publication of Adam Smith's Wealth of Nations (1776) which is widely seen as the birth of modern economics. The issues covered will be mercantile policy; usury and interest rates; taxation; and finally and most importantly monetary thought. The conclusions will discuss the differences and similarities found across Eurasia so as to show the value of more global outlook.

\section{Anti-Mercantile Sentiments}

Chinese premodern economic thought is usually cast as anti-mercantile, yet the ancient Greeks often regarded trade as degrading too; they saw price speculation as nasty, an activity which was to be denounced even by Socrates. Sparta banned its citizens from pursuing trade altogether, and such attitudes were reflected by Plato and Aristotle (Meikle, 1995: pp. 68-81). This is despite the fact that Aristotle's thought is otherwise geared toward private property and slavery, the latter largely absent from Chinese classics (Wilbur, 1966).

Against this background it bears recalling that, the Book of Lord Shang apart, resolute anti-mercantile attitudes in Chinese classics had been few before the 
Western Han Dynasty (206 BCE -25 CE). In antiquity one finds enthusiastic advocates for commerce like Spring-and-Autumn-era Fan Li and Ba Gui. Even hardnosed philosopher like Xunzi (c. BCE 310-235) who would later denounce merchants was otherwise in favour of international trade. He did not support equalization of wealth either (Hu, rep. 2009: p. 171; Sterckx, 2015).

Lord Shang (BCE 390-338), who established Legalism, advocated the equalization of wealth across the populace so that the state would be rich and they poor. He also called for the heavy taxation of commerce so as to raise the price of grain staple (Hu, rep. 2009: p. 176, pp. 186-195; Pines, 2019). One of the great critics of Legalism, the historian Sima Qian (BCE 145-86), was later against high taxation, and in favour of commerce; he saw different wealth levels as naturally resulting from varying talent levels in society ( $\mathrm{Hu}$, rep. 2009: pp. 242-248). However, in the same breath, Sima believed the volume of wealth in nature was fixed, so more for one necessarily meant less for another (Hu, rep. 2009: p. 201).

The Confucian canon as such is anti-mercantile but favouring limited government. Yantie Lun and Guanzi are ancient formative texts, which in turn pronounce largely Legalist ideas. Amongst other things, they support government price control reminiscent of the later Muslim hisba. But it is more far-reaching than that: the Guanzi proposed controlling the price level through the timely increase or reduction of the money supply. In sum, after the Han dynasty (BCE 202-CE 220), there was in China more interventionism than in either Europe or the Islamic world, as evidenced by the government monopolies in existence (Hu, rep., 2009: p. 157).

But there were also Confucian minority voices in the Yantie Lun that like later French physiocrats resiled from interventionism (Hu, rep., 2009: p. 277). They complained for example that the government's iron monopoly produced faulty and expensive utensils, so much so that peasants reverted to wooden spades (Schefold, 2019). Similar sentiments were later echoed by premier Qiu Jun (1421-1495) who opposed the government going into money lending, but supported international trade (Hu, rep., 2009: pp. 448-452).

In the late imperial period, finally, anti-mercantile sentiments were relaxed. Three of the most influential thinkers at the time, Wang Fuzhi (1619-1692), Huang Zongxi (1610-1695) and Gu Yanwu (1613-1682), are compared to European Enlightenment thinkers in that they supported commerce and industry, and opposed government tyranny (Hu, rep., 2009: p. 481).

Doubtless, Bernard Mandeville (1670-1733) was a European trail-blazer, as hitherto in most civilizations mainstream opinion saw luxury in negative terms. Prominent Muslim scholar Naser a-Din a-Tusi (1201-1274) for example railed against conspicuous consumption (Hosseini, 2014). And Christianity had been influenced by Aristotle's anti-commerce stance centuries long before. Aristotle thought that trading was not a natural pursuit: traders were not productive in the same sense as farmers. Indeed, in Chinese traditional thought, farming is the fundamental pursuit (Pangle, 2014: Chp. 1).

Yet precocious pro-commerce ideas did arise in medieval Islam (in fact at the 
time Islam was more pro-commerce than either Christianity or Confucianism): for example Kai Kavus (1050-1087) advocated wealth accumulation, and understood the importance of trade. Or Jalaladdin Davani (1426-1502), who recommended on his part splitting wealth between land and money.

European mercantilists were prescribing big government, international trade and manufacturing, while French physiocrats (who had been influenced by Chinese thought) stressed agriculture and small government. Moreover, mercantilist Thomas Mun (1571-1641) preached import restrictions because England had no mines from which to produce precious-metal coin. His fear was that England, through trade deficit, might haemorrhage coin overseas. John Locke (1632-1704) and Charles Davenant (1656-1714) on the other hand pointed out that trade surpluses would incur higher prices at home (Kurz, 2016: pp. 2-3). The same point was later made by Adam Smith (1723) and David Ricardo (1790).

\section{Usury and Prices}

It is well known the Scholastics in medieval Europe banned usury, but they were not against profit per se. Their "just price theories" are imputed today for example to both modern socialism and neo-classical theory origins. Much like Sima Qian, the Scholastics also believed money was sterile - it could not yield benefit of its own (de Roover, 1967).

Of course the Old Testament and Kuran forbade usury to begin with. But in discussing inhibitions on finance, it is often forgotten that Plato and Aristotle had been opposed to usury too, and their attitude influenced (via Arab sources) Thomas Aquinas (1225-1274), Francisco Vitoria (1483-1546) and the Scholastic medieval literature (Kurz, 2016: p. 10; Wilson, 1997: pp. 32-33; Baeck, 1994: p. 92). In China attitudes to usury were much more relaxed though it was momentarily opposed in the Tang era (618-907) (Hu, rep., 2009: p. 353).

Direct usury emerged in Europe only in $13^{\text {th }}$ century. Yet it may be that in China as early as the Western Zhou era (BCE 1045-771) the government had been a lender, and interest rates were at 10\% - 20\% per annum (Hu, rep., 2009: pp. 10-11; Amelung \& Schefold eds., 2021: p. 284). In Islam, too, a range of bypasses were created so as lending could take place, and these are known as hiyal (Saeed, 1996).

\section{Taxation}

In China, the Confucian tradition prescribed a land tax of no more than $10 \%$ (Dasgupta, 2002: pp. 53-54). Similarly, medieval Muslim scholar Abu Yusuf (d. 798) favoured proportional tax rather than fixed tax on land (Siddiqi \& Ghazanfar, 2001).

Like China, Indian ancient economic thought stressed the creation of state monopolies (except textile), and also the protection for traders in return for an impost (Dasgupta, 2002: p. 32; Kautilya rep., 2000). But there was a higher land tax of up to one third of the crop stipulated by the Muslim era (Dasgupta, 2002: 
p. 34). Alaudddin Khiji (r. 1296-1316) went as far as setting the land tax bar at $50 \%$ so as to suppress potential rebels, but his was an aberration (Dasgupta, 2002: p. 49).

\section{Money}

The classical notion of money, as articulated by David Hume (1711-1776), was that real wealth consisted of commodities; that the amount of money in circulation should be kept relative to the amount of goods in the market that a low rate of interest is a symptom not of superabundance of money but of booming trade; that no nation can go on exporting only for bullion (Schabas \& Winnerlind, 2020).

However, such assumptions had many forerunners around the world going back to antiquity. For example The Chinese sage Mozi (BCE 470-391) like Aristotle distinguished between value and exchange value. And the Legalist Guanzi offered one of the earliest formulations of the quantity theory of money. Finally and most pertinently, Chao Cuo (BCE 200-154) suggested coinage on its own was worthless, it could not feed the hungry ( $j i$ bu ke shi). Here, we are reminded of course of Aristotle's citation of King Midas whose touch turned everything to gold, but starved to death because he could not turn gold to food (Fuller ed., 2020: p. 27).

This was a trope that was later used by other nominalists. A step further and earlier from Chao, Gong Yu (BCE 124-44) recommended the abolition of metal coinage altogether to remedy the abandonment of farming (Hu, rep., 2009: pp. 287-288). In the Six Dynasties era (3 - 6 Centuries CE) there were fetishistic views of money, alongside fringe proposals to abolish it altogether, but government monopoly on coinage was as, an idea at least, preserved (Hu, rep., 2009: pp. 322-325).

Ibn Rushd (Averroes) renewed interest in the West in Aristotelian thinking. Unfortunately, his rationalism was denounced in Islam while alive. He was preceded by Al-Farabi (872-950) who had tried to rid Islam from neo-Platonist mysticism. Ibn Rush like Aristotle thought money to be mere media of exchange (Baeck, 1994: pp. 111-114).

Somewhat like Hume and Chao much earlier, famous Muslim scholar al-Ghazali (d. 1111) argued gold and silver coins were useless in and of themselves. He also fulminated against the harmful effect of debasement and counterfeiting, pre-saging Nicholas Oresme (1320-1382). Finally, al-Ghazali condemned usury because it made money deviate from its purpose as a medium of exchange (Ghazanfar, 2014: pp. 202-215). Later, historian al-Maqrizi (1365-1442) also inveighed against debasement as enriching the ruler and the well-heeled at the expense of commoners (Baeck, 1994: pp. 105-107). Finally, on the other corner of Eurasia, Russian thinker I. Pososhkhov also expressed nominalist views, claiming somewhat like Jean Bodin that (1530-1596) the tsar could determine coin values by decree regardless of their intrinsic value (Letiche, 1964; Bodin 
rep., 1992).

Bernardo Davanzati (1529-1606), Gasparo Scaruffi (1519-1584) and Antonio Serra (b. 1568) were in contrast to Hume supporters of mercantilism and metallism, the latter being in part the idea that the value of money depends on precious metals of which it was made. This too had forerunners in premodern economic thought. Somewhat Like mercantilist, medieval Chinese scientist Shen Kua (1031-1095) was for example, in favour of banning imports so as to reduce the outflow of Chinese coin. Shen was also in favour of using gold coinage instead of copper one, and lifting the ban on private copper mining ( $\mathrm{Hu}$, rep., 2009: pp. 392-393).

During the Qianlong reign in the $18^{\text {th }}$ Century, Chinese observers noted that increased output of coin was accompanied by dearer relative prices. This was because the coins proved increasingly popular. In fact, Such situation had been pre-saged by Abu Yusuf, who noted an abundance of goods can attend higher prices, and scarcity can sometimes attend lower ones (Siddiqi \& Ghazanfar, 2001).

Early exhortations against debasement in Chinese sources are many. The best known and earliest is Shan Qi's rebuke of King Jing of Zhou for wanting to debase coinage through issuing a bigger coin (Hu rep., 2009: p. 25). This is reminiscent later of Ibn Khaldun who was too against permutation in size as disrupting price stability (Baeck, 1994: pp. 115-116).

In between, Kong Ji of the Southern Qi dynasty (r. 479-502) declared in the same vein that the fault with coinage lies in the ever recurrent changes in its weight. Heavier money was handicapped by sluggishness in its circulation but sluggishness was a lesser evil. Rather, the trouble with the lighter money was that it incentivized illicit coinasge (Hu rep., 2009: pp. 328-329).

Influenced by scholar-official Jia Yi (BCE 200-169), by Yantie Lun and Guanzi most Chinese dynasties would disallow free coinage, imposing a government monopoly on mining (Hu rep., 2009: pp. 229-230). The key intellectual aberrations prescribing free coinage were Shen Qingzhi (386-465) of the Northern Wei dynasty and Zhang Jiuling (678-740) of the Tang dynasty ( $\mathrm{Hu}$ rep., 2009: p. 327).

\section{Conclusion}

This research note has realigned diachronically leading economic thinkers from antiquity, the medieval era and the early modern era with a view toward teasing out differences and similarities across Eurasia, particularly as regards early monetary theory. The provisional findings are that, firstly, economic activity in China was perceived in its interaction with the state. To almost the same degree, this was also the situation in India. However, more private space was allowed for in the West. Most economic matters in the West begin with the household.

China's induction into modern economics arguably begins with Ma Jianzhong (1845-1900). Ma studied in France, and proposed modernizing the Chinese 
money system by minting silver dollars instead of the current ingots. He also recommended minting gold dollars to align with gold standard countries, and promoting joint-stock enterprise (Hu rep., 2009: pp. 542-543).

Unlike Ma's approach, Chinese premodern economic thought had on the whole clearly been anti-mercantile. But as mentioned the ancient Greeks often regarded trade as degrading too; it was not until the late-imperial period that anti-mercantile sentiments were relaxed, and it was not hard to find thinkers who around the same time come close in their espousal of the private space to European enlightenment thinkers. Against the backdrop of Confucian inhibitions and Scholastic literature, medieval Islam was by far the most tolerant of commerce, but that attitude was eclipsed by European advancement in the renaissance. When it came to usury per se the Koran was very strict, more so than in Christendom or in China.

All large premodern empires relied on land tax, but in China there was a solid body of thought weighing down on rulers to reduce tax rate. In that sense, the Legalist school which prescribed higher taxes did not win over. In China, the rate rarely rose above $1 / 10$ of the crop, while in India and Europe the rate was in all likelihood much higher (Huang, 1974; Roy, 2012; Webber \& Wildavsky, 1986).

In China and to a lesser extent India coinage was prerogative of the state. It was much less so in Europe where bishoprics and moneyers often had the right to mint, and where monetary integration was later in coming, as Bodin's exhortations might suggest. Ideationally, the default mode in China was to view money as means to an end. This echoes al-Ghazali and others, as we have seen. Finally, in all three civilizations alarm has been expressed over ruler's penchant for debasement.

\section{Research Limitations}

1) Like China, it was noted that Indian ancient economic thought stressed the creation of state monopolies. But there was a higher land tax of up to one third of the crop stipulated during the Muslim era. What we are still lacking is a comprehensive comparative introduction to the tax regimes of premodern polities. 2) The conclusions show that monetary nominalism was pervasive around the world; and that Islamic thinkers were the least anti-mercantile. Based on the conclusions, a more theoretical, full-length discussion of the significance of this note is necessary. At any rate, one must consider that the monetary thinkers of pre-modern times spread as they were across continents were more often than not unaware of their peers' ideas.

\section{Conflicts of Interest}

The author declares no conflicts of interest regarding the publication of this paper.

\section{References}

Amelung, I., \& Schefold, B. (2021). Towards a Systematic Comparison of Different Forms 
of Economic Thought. In B. Schefold, \& I. Amelung (Eds.), European and Chinese Histories of Economic Thought: Theories and Images of Good Governance (pp. 277-300). Routledge. https://doi.org/10.4324/9780367434496-30

Baeck, L. (1994). Mediterranean Tradition in Economic Thought. Routledge.

Barber, W. (1967). A History of Economic Thought. Wesleyan University Press.

Barnett, V. (2014). Handbook of the History of Global Economic Thought. Routledge. https://doi.org/10.4324/9781315761084

Bodin, J. (1992). On Sovereignty. Cambridge University Press.

Dasgupta, A. K. (2002). A History of Indian Economic Thought. Routledge. https://doi.org/10.4324/9780203003473

De Roover, R. (1967). The Scholastics, Usury and Foreign Exchange. Business History Review, 41, 257-271.

Fuller, E. (2020). A Source Book on Early Monetary Thought: Writings on Money before Adam Smith. Edward Elgar. https://doi.org/10.4337/9781839109997

Ghazanfar, S. M. (2014). Arab-Islamic Economics. In V. Barnett (Ed.), Handbook of the History of Global Economic Thought (pp. 202-215). Routledge.

Hofstede, G. (1984). Culture's Consequences: International Differences in Work-Related Values. Sage.

Hosseini, H. (2014). Persia/Iran. In V. Barnett (Ed.), Handbook of the History of Global Economic Thought (pp. 216-227). Routledge.

$\mathrm{Hu}, \mathrm{J}$. (2009). Concise History of Chinese Economic Thought. Foreign Languages Press.

Huang, R. (1974). Taxation and Governmental Finance in Sixteenth-Century Ming China. Cambridge University Press.

Kautilya (2000). Arthashastra. Peguin.

Kurz, H. (2016). Economic Thought: A Brief History. Columbia University Press. https://doi.org/10.7312/kurz17258

Letiche, J. (1964). A History of Russian Economic Thought: Ninth through Eighteenth Centuries. Cambridge University Press.

Medema, S., \& Samuels, W. (2013). The History of Economic Thought: A Reader. Routledge. https://doi.org/10.4324/9780203568477

Meikle, S. (1995). Aristotle's Economic Thought. Clarendon.

Pangle, T. (2014). Aristotle Teaching in the Politics. University of Chicago Press.

Pines, Y. (2019). The Book of Lord Shang. Columbia University Press.

Pines, Y., \& Shelach, G. (2005). 'Using the Past to Serve the Present': Comparative Perspectives on Chinese and Western Theories of the Origins of the State. In S. Shaked (Ed.), Genesis and Regeneration: Essays on Conceptions of Origins (pp. 127-163). Jerusalem: The Israel Academy of Science and Humanities.

Rauschenbach, S., \& Windler, C. (2016). Reforming Early Modern Monarchies: The Castillian Arbitristas in Comparative European Perspective. Harrassowitz.

Roy, T. (2012). India in the World Economy. Cambridge University Press.

Saeed, A. (1996). Islamic Banking and Interest. Brill.

Sandelin, B., Trautwein, H. M., \& Wundrak, R. (2014). A Short History of Economic Thought. Routledge. https://doi.org/10.4324/9781315770895

Schabas, M., \& Wennerlind, C. (2020). A Philosopher's Economist: Hume and the Rise of Capitalism. University of Chicago Press.

https://doi.org/10.7208/chicago/9780226691251.001.0001 
Schefold, B. (2019). A Western Perspective on the Yantie Lun. Routledge. https://doi.org/10.4324/9781315162911-9

Schefold, B., \& Amelung, I. (2021). European and Chinese Histories of Economic Thought: Theories and Images of Good Governance. Routledge.

Siddiqi, M. M., \& Ghazanfar, S. M. (2001). Islamic Economic Thought: Abu Yusuf's (731-798 AD) Economics of Public Finance. History of Economic Ideas, 9, 13-38.

Sterckx, R. (2015). Ideologies of the Peasant and Merchant in Warring States China. In Y. Pines, P. R. Goldin, \& M. Kern (Eds.), Ideology of Power and Power of Ideology in Early China: Studies in Early Chinese Political Thought (pp. 211-248). Brill.

Von Mises, L. (2005). Theory and History. Liberty Fund.

Webber, C., \& Wildavsky A. (1986). A History of Taxation and Expenditure in the Western World. Simon \& Schuster.

Wilbur, M. (1966). Slavery in China during the Forsmer Han Dynasty, 206 BC-AD25. Field Museum of Natural History.

Wilson, R. (1997). Economics, Ethics and Religion. Palgrave. https://doi.org/10.1057/9780230374720

Zanasi, M. (2015). Frugality and Luxury: Morality, Market, and Consumption in Late Imperial China. Frontiers of History in China, 10, 457-485. 